\title{
Hilar Arteriovenous Pattern in a Case of Horseshoe Kidney
}

\author{
Ana Paula Gobate Miorin ${ }^{1}$ Rôksanny Carneiro Carrijo Cabral ${ }^{1}$ Rafael Bellini ${ }^{1}$ Fernando Batigália ${ }^{2}$ \\ Erivelto Luís Chacon ${ }^{3}$ Nagib Pezati Boer ${ }^{1}$
}

1 Department of Anatomy, Universidade Brasil, Fernandópolis, SP, Brazil

2 Department of Anatomy, Faculdade de Medicina de São José do Rio Preto, São José do Rio Preto, SP, Brasil

3 Department of Anatomy, Centro Universitário Padre Anchieta, Jundiaí, SP, Brasil

J Morphol Sci 2018;35:229-232.
Address for correspondence Ana Paula Gobate Miorin, Departamento de Anatomia, Universidade Brasil, Estrada projetada F1, s/n, Fazenda Santa Rita, CEP 15.600-000, Fernandópolis, SP, Brasil (e-mail: ana_gobate@hotmail.com).

\begin{abstract}
Keywords

- horseshoe kidney

- anomaly

- artery

- vein

- anatomy
\end{abstract}

\section{Introduction}

Kidneys are oval-shaped organs that are situated in the retroperitoneum, on the posterior abdominal wall, one on each side of the vertebral column, at the level of the T12-L3 vertebrae. They have a reddish-brown color and are $\sim 10 \mathrm{~cm}$ long, $5 \mathrm{~cm}$ wide, and $2.5 \mathrm{~cm}$ thick. The right kidney is located $\sim 2.5 \mathrm{~cm}$ lower than the left kidney, probably because of the liver. The lower pole of the right kidney is approximately one finger width above the iliac crest. ${ }^{1}$

received

September 27, 2017

accepted

October 2, 2017
DOI https://doi.org/

10.1055/s-0038-1675763. ISSN 2177-0298.
Horseshoe kidney is the most common congenital malformation of the urinary system, and it combines three anatomical variations: ectopia, poor rotation, and vascular change. ${ }^{2}$ In most of the cases, the fusion occurs through the lower renal poles with the formation of an isthmus of fibrous tissue that crosses the median line, which prevents the kidney from ascending from the pelvis to the abdominal cavity due to the presence of the inferior mesenteric artery, at the level of the third to the fifth lumbar vertebrae. Due to

Copyright $\odot 2018$ by Thieme Revinter Publicações Ltda, Rio de Janeiro, Brazil

\section{License terms}

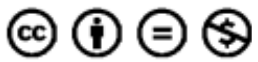




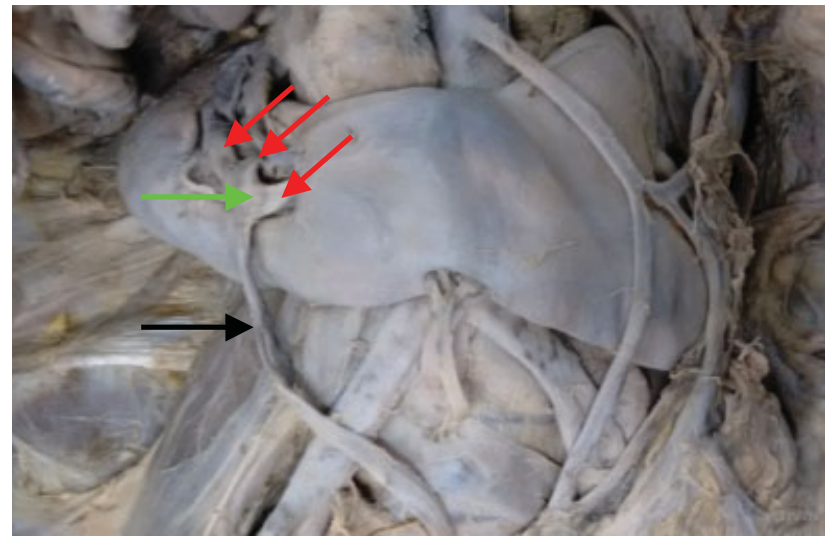

Fig. 1 Right anterior aspect of the horseshoe kidney (green arrow: renal pelvis; red arrows: larger renal calyces; black arrow: abdominal part of the ureter).

this fact, they do not rotate $90^{\circ}$ anteriorly, which damages the arteriovenous formation, giving rise to numerous accessory vessels. ${ }^{2-4}$

This malformation has a prevalence of $0.25 \%$ ( 1 in 400 births) and a higher rate in males (2:1 or 3:1). The arrangement of the arteries and veins in the renal hilum varies considerably, which can compress the ureters and cause urinary lithiasis in up to $41 \%$ of the cases. ${ }^{5,6}$ The anomalous anatomical position predisposes to a greater risk of blunt injuries. ${ }^{3}$ In addition, the horseshoe kidney has also been related to a greater propensity to neoplasias, such as Wilms tumor, and to systemic malformations, such as Turner syndrome. $^{7}$

The blood supply to the horseshoe kidney is varied, with the arteries originating from branches of the aorta, from the inferior mesenteric artery, or from the iliac artery. ${ }^{8}$ The identification of the anatomical variations of the renal arteries is of extreme importance for the performance of surgical procedures involving the renal arteries in order to prevent reckless lesions during surgery. This study cooperate especially in surgical interventions, as well as in renal transplants and radiological studies. ${ }^{9-11}$

The objective of the present study is to report the arteriovenous pattern found in the renal hilum in a case of horseshoe kidney.

\section{Materials and Methods}

A conventional retroperitoneal dissection was performed in a corpse, fixed for 2 years in formalin, of a 64-year-old adult female, brown skin color, legally belonging to the Anatomy Laboratory of Unicastelo, Fernandópolis, state of São Paulo, Brazil, with causa mortis related to uterine cancer.

\section{Results}

Horseshoe kidney (-Fig. 1) was detected, with a union pattern at the lower extremities formed by an isthmus with a concavity facing upwards. The right kidney was $5.69 \mathrm{~cm}$ long, $3.62 \mathrm{~cm}$ wide, and had an average thickness of $2.68 \mathrm{~cm}$. The left kidney was $11.65 \mathrm{~cm}$ long, $5.02 \mathrm{~cm}$ wide, and had an average thickness of $2.82 \mathrm{~cm}$. The distance between the 2 upper poles was $9 \mathrm{~cm}$, with a convex margin of $37 \mathrm{~cm}$, and a concave margin of $19.5 \mathrm{~cm}$. The ureters originated from an anomalous and extruded renal pelvis; however, with a normal path and topography ( $\mathbf{- F i g . 1} \mathbf{1}$ ).

In a comparison with the usual pattern of renal arterial supply ( - Fig. 2), the following variations could be observed (-Figs. 3 to 6): single right superior polar segmental artery with right posterior artery; double left superior polar segmental arteries originating from the renal artery (one in each renal face); renal isthmus artery originating from the posterior aspect of the abdominal aorta; and a vein from the renal isthmus opening into the left common iliac vein.

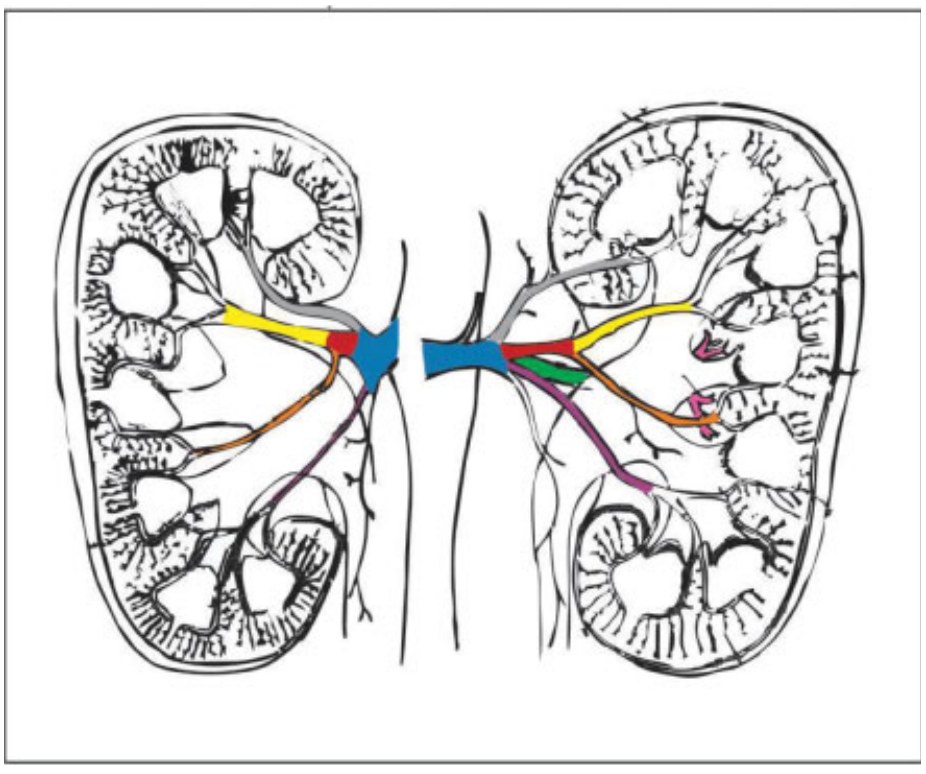

\begin{tabular}{|l|}
\hline Renal artery \\
Anterior branch of the renal artery \\
Pupterior branch of the renal artery \\
Anterior superior segmental anterior artery \\
Anterior inferior segmental artery \\
Inferior segmental artery \\
\hline
\end{tabular}

Fig. 2 Renal arterial pattern. 


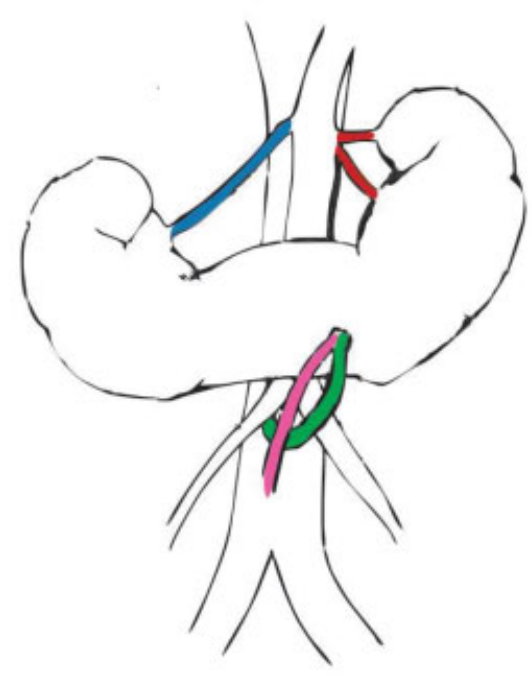

Right superior polar segmental artery

Left superior polar segmental arteries

Renal isthmus artery

Renal isthmus vein

Fig. 3 Blood supply found in a case of horseshoe kidney.

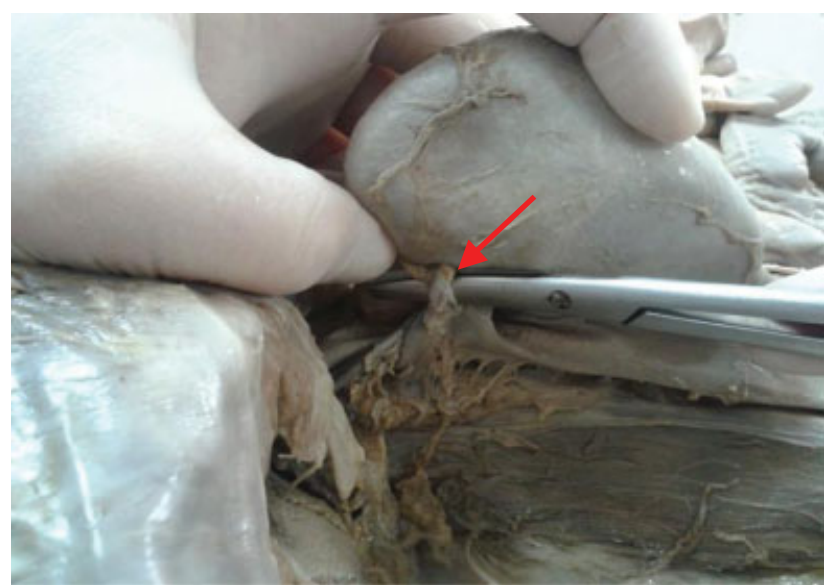

Fig. 4 Presence of right superior polar segmental artery (red arrow) in posterior view, after the dislocation of the horseshoe kidney.

\section{Discussion}

Horseshoe kidneys are asymptomatic and are usually detected at random. However, they are subject to a series of complications as a result of poor drainage, which may lead to clinical symptoms. ${ }^{3,12}$ These complications include hydronephrosis secondary to obstruction of the ureteral junction, infection and renal calculi, increased incidence of malignancy (especially Wilms tumor and transitional cell carcinoma), and increased susceptibility to trauma. ${ }^{3,12,13}$ Glomerulonephritis is another complication, with immunoglobulin A nephropathy being the most common in horseshoe kidneys. ${ }^{13}$

The most probable explanation for the formal genesis of the anomaly of the present case is the fusion of the two caudal poles during a period in which two renal sketches were very close, mainly at the lower poles. As a result, the mesodermal tissue among the methanephrons disappears or does not carry out its normal development. For reasons that are not yet determined, the lower poles of the kidneys are

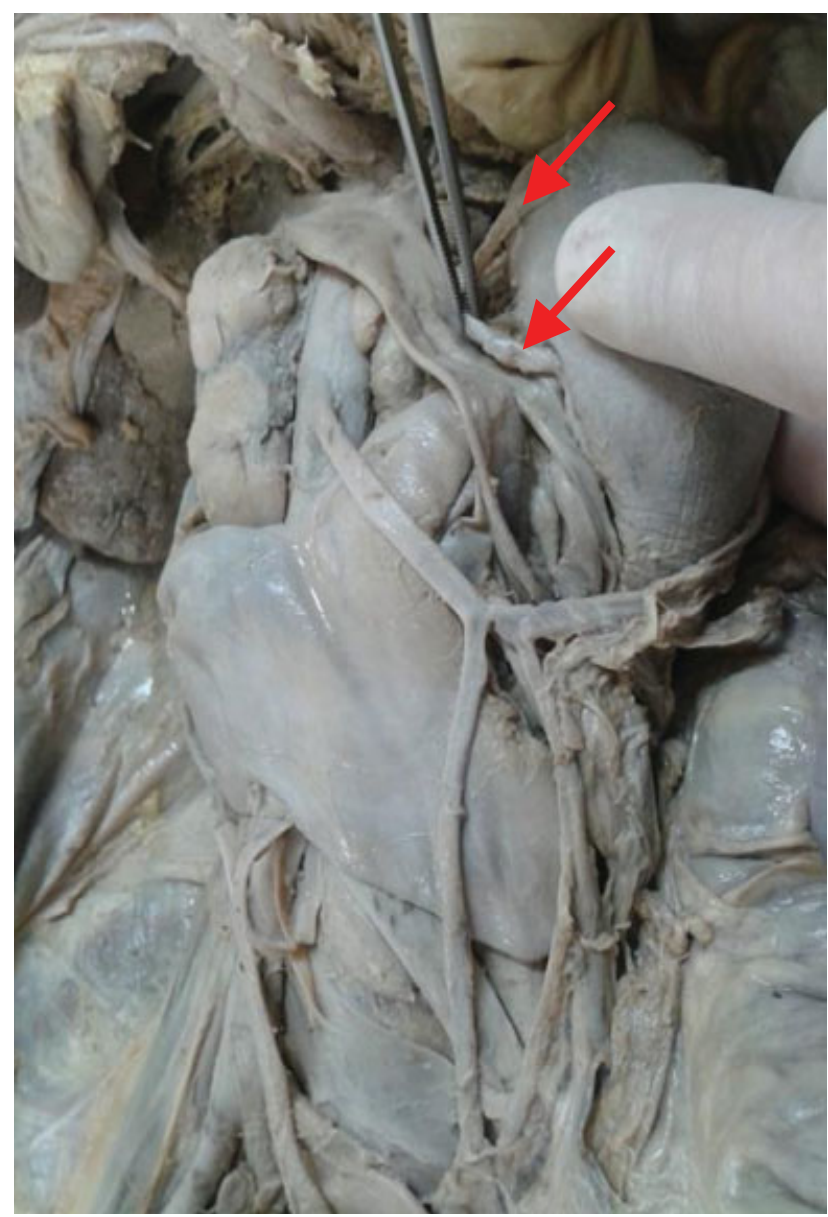

Fig. 5 Presence of two left superior polar segmental arteries (red arrows) in horseshoe kidney.

close to merge. This merge explains the successive stop of rotation along the longitudinal axis. ${ }^{7,12}$

The blood supply is, in most cases, anomalous, being composed of several accessory vessels. ${ }^{3}$ This variation was classified in different ways and is important for surgical programming. $^{14}$ 


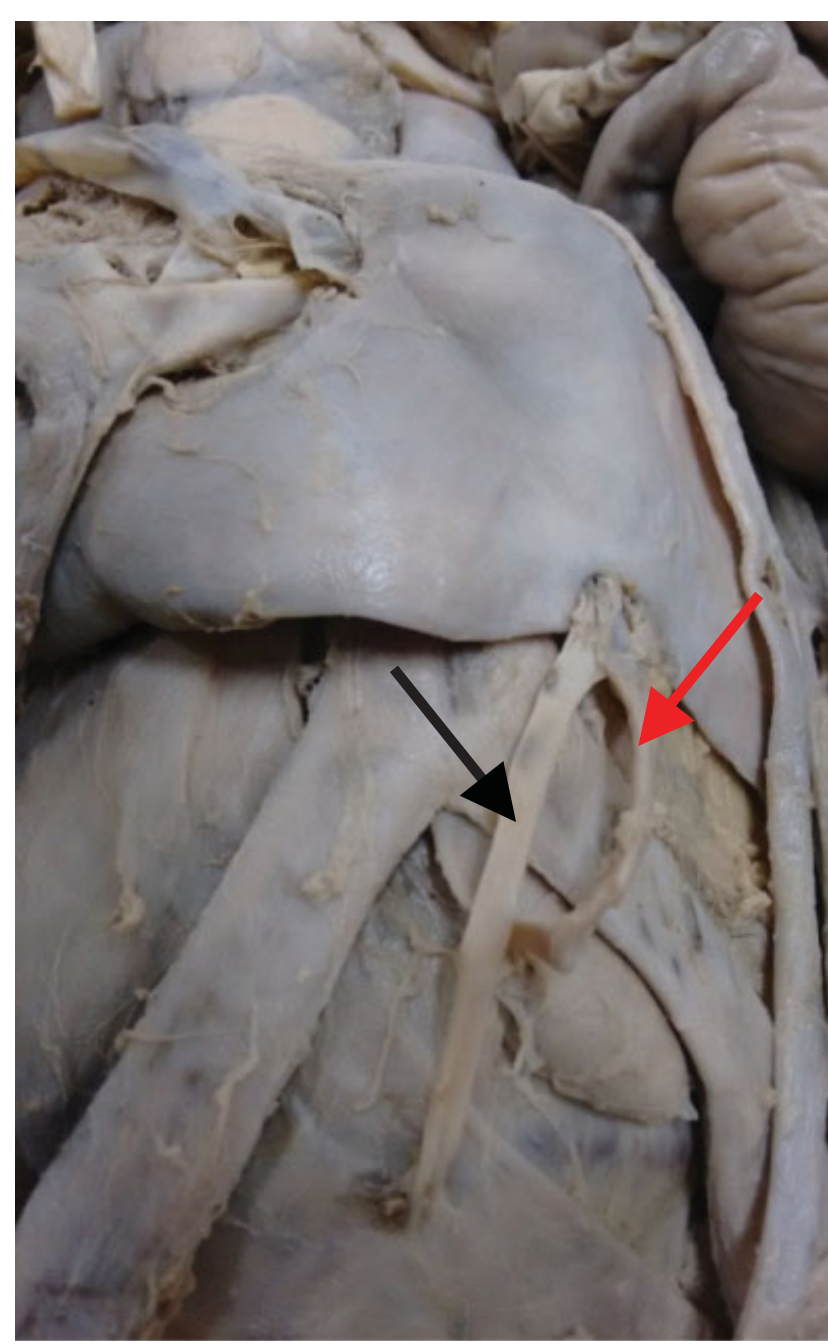

Fig. 6 Detection of the artery (red arrow) and of the vein (black arrow) of the renal isthmus in a case of horseshoe kidney.

\section{Conclusion}

Horseshoe kidney is a congenital anomaly whose arteries can originate from branches of the aorta, from the inferior mesenteric artery, or from the iliac artery. Its veins drain into the renal vein, into the inferior vena cava, or into the iliac veins. Although it may be associated with hydronephrosis and nephroblastoma, no reports were found in the literature regarding the correlation between horseshoe kidney and uterine cancer, which highlights the importance of the hilar vascular pattern of the reported case.

\section{References}

1 Moore KL. Anatomia Orientada para Clínica. $6^{\circ}$ ed. Rio de JaneiroGuanabara Koogan2011

2 Natsis K, Piagkou M, Skotsimara A, Protogerou V, Tsitouridis I, Skandalakis P. Horseshoe kidney: a review of anatomy and pathology. Surg Radiol Anat 2014;36(06):517-526

3 Sakala MD, Dyer RB. The horseshoe kidney. Abdom Imaging 2015; 40(07):2910-2911

4 Schiappacasse G, Aguirre J, Soffia P, Silva CS, Zilleruelo N. CT findings of the main pathological conditions associated with horseshoe kidneys. Br J Radiol 2015;88(1045):20140456

5 Ishii H, Rai B, Traxer O, Kata SG, Somani BK. Outcome of ureteroscopy for stone disease in patients with horseshoe kidney: Review of world literature. Urol Ann 2015;7(04):470-474

6 Rodriguez MM. Congenital Anomalies of the Kidney and the Urinary Tract (CAKUT). Fetal Pediatr Pathol 2014;33(5-6):293-320

7 Maranhão CPM, Miranda CMNR, Santos CJJD, Farias LPG, Padilha IG. Anomalias congênitas do trato urinário superior: novas imagens das mesmas doenças. Radiologia Brasileira, São Paulo 2013; 46(01):43-50

8 O'Brien J, Buckley O, Doody O, Ward E, Persaud T, Torreggiani W. Imaging of horseshoe kidneys and their complications. J Med Imaging Radiat Oncol 2008;52(03):216-226

9 Hau HM, Morgul HM, Uhlmann D, et al. Horseshoe kidney for transplantation: technical considerations. Scand J Urol 2013;47 (01):76-79

10 Jaffer F, Chandiramani V. Concomitant persistent left superior vena cava and horseshoe kidney. Case Rep Nephrol 2015;2015:178310

11 Silvestre JMS. Tratamento endovascular de aneurisma de aorta abdominal em paciente com rim em ferradura: relato de caso. J Vasc Bras 2013;12(01):62-67

12 KERR Lucy e WELTER, Stephanie. Rins em Ferradura - Artigo de Revisão para Médicos Especialistas em Imagem. Lucy Kerr, apr 2015. Available in http://www.portallucykerr.com/artigos/rinsem-ferradura. Access in 18 Apr. 2016.

$13 \mathrm{Hu}$ P, Jin M, Xie Y, et al. Immunoglobulin A nephropathy in horseshoe kidney: case reports and literature review. Nephrology (Carlton) 2014;19(10):605-609

14 Garcidueñas-Briceño CM, Bobadilla-Flores NO. Aneurisma de aorta abdominal roto asociado com riñón em herradura: presentación de caso y revisión de la literatura. Revista Mexicana de Angiologia 2012;40(02):68-71 